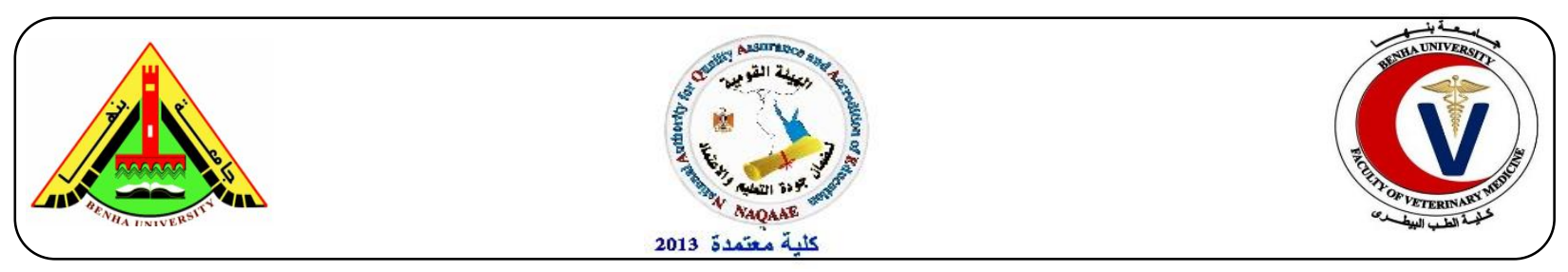

\title{
Staphylococci in some meat products
}

Faten S. Hassanin $a$; Mohamed A. Hassan ${ }_{a}$; Shimaa M. Nada.b and Sarah M. Badr

a. Food Control Dep., Fac. Vet. Med., Benha Univ.

b. Animal Health research institute, Shebin Elkoom branch.

\section{A B S T R A C T}

Meat products are liable to harbor different types of micro-organisms during long chain of handling, processing, distribution and storage as well as preparation, so a total of 90 random samples of locally manufactured meat products represented by frozen beef burger (30), kofta (30) and sausage (30) "25 grams of each" were randomly collected from different shops in El-Menoufia governorates, Egypt. It is evident from the obtained results that all the examined samples of beef burger, kofta and sausage were positive Staphylococci On the other hand,S.aureus detected in $40 \%, 46.67 \%$ and $63.33 \%$ in examined samples of beef burger, kofta and sausage, respectively. Serological examination declared that the incidence of Staphylococcus species from examined beef burgers were $40 \%, 23.33 \%$ and $3.33 \%$ for S.aureus, S.epidermidis and S.intermedius, respectively. While, in kofta were $46.67 \%, 26.67 \%$ and $6.67 \%$ for S.aureus, S.epidermidis and S.saprophyticus, respectively and in sausage were 63.33\%, 36.67\%, 10\%, 13.33 and 6.67 for S.aureus, S.epidermidis, S.intermedius, S.saprophyticus and S. xylosus, respectively. Whilst, the detected S.aureus enterotoxins from examined samples were enterotoxin B in beef burger with incidence of 3.33\%, enterotoxin $\mathrm{A}$ and enterotoxin $\mathrm{C}$ with incidence of $3.33 \%$ and 3.33, respectively from kofta samples. While in sausage sample enterotoxin A, B and D\&C were detected with incidence of $10 \%, 3.33 \%$ and $3.33 \%$, respectively.The presence of these microorganisms in large numbers make these meat products of inferior quality and unfit for human consumption.

Key words: Staphylococci,S. aureus, beef burger, kofta, sausage, Enterotoxins.

(http://www.bvmj.bu.edu.eg)

(bvmj, 34(1):1-9, MARCH, 2018

\section{INTRODUCTION}

Foods of animal origin including meat are required to maintain the health of human body (Nestle, 1999) and they are highly demanded due to their high biological value, responsible price, agreeable taste and easily serving.On the other hand these benefits come over the safety and the quality of such food items because the vendors have lack of information about the basic food safety rules (Gibbons et al., 2006).

Foodborne infection and intoxication outbreaks are increasing day by day in industrial and developing countries, the majority of cases of foodborne diseases were due to bacterial agents (Stevenson and Bernard, 1995). Staphylococcus spp can be carried on hands, nasal passage or throats. Most food borne illness outbreaks are result of contamination from food handlers and production of heat stable toxins in food. (FSIS, 2003) and the most common way for food contamination with Staphylococcus is through contact with food workers who carry the bacteria. (CDC, 2006).

Staphylococcal food poisoning is the result of preformed enterotoxins that are produced by certain strains of S.aureus resulting in symptoms of intoxication, not 
infection. The most common symptoms appear approximately 3-8 hrs after ingestion and include nausea, vomiting, abdominal cramps and diarrhea. Generally, symptoms are short in duration (approximately $24-48$ hrs) (Sandel and Mckillip, 2004).

Therefore, this work was planned out to study the bacteriological contamination in some locally manufactured meat products from different local commercial shops in Menoufia government, Egypt to investigate the following: Determination of Staphylococci and S. aureus count; and isolation and then identification of Staphyloccocal species, S.aureus and some of its enterotoxins.

\section{MATERIAL AND METHODS}

\subsection{Collection of samples:}

Ninety random samples of locally manufactured meat products represented by frozen beef burger(30), $\operatorname{kofta}(30)$ and sausage(30) of 25 grams from each examined sample were collected from different shops supermarkets in Menoufia government, Egypt. All collected samples were separately kept in sterile plastic bag and transferred in an ice box to the laboratory under complete aseptic conditions without undue delay. The samples were subjected to the bacteriological examination for detection of Staphylococcus aureus in such products.

2.2.Preparation of samples (ICMSF, 1996).

2.3. Determination of Staphylococci and $S$. aureus count (FDA, 2001).

The method described by (FDA, 2001) and the developed colonies appeared on Baired Parker agar plate after incubation at $37^{\circ} \mathrm{C}$ for 48 hours. The suspected colonies of Staph .aureus appear as black, shiny, circular, smooth, convex with narrow white margin and surrounded by a clear zone extending into opaque medium were enumerated and Staphylococcus aureus count /gwas calculated. Also, the colonies were picked up and purified on nutrient agar slopes for further morphological, biochemical and serological examination identification.

2.4. Identification of Staphylococci species.

2.5. Detection of Staphylococcus aureus enterotoxins.

The serologically identified $S$. aureus strains were examined for their ability to produce enterotoxins using Staphylococcal Enterotoxin -Reverse Passive Latex Agglutination kit (SET-RPLA) and Sac culture method recommended by (Oda et al., 1979).

2.6. Detection and typing of $S$. aureus enterotoxin (Shingaki, et al., 1981):

The clear culture supernatant fluid was tested serologically by RPLA technique using kits for the detection of staphylococcal enterotoxins A, B, C and D (SET-RPLA, Denka Sekeu LTD, Japan for OxoidLTd).

2.7. Statistical analysis: according to Feldman et al. (2003).

\section{RESULTS}

It is evident from the results recorded in table (1) that all the examined samples were positive staphylococci with mean value (cfu/g) $4.07 \times 10^{3} \pm 0.69 \times 10^{3}$ for beef burger, $9.52 \times 10^{3} \pm 2.14 \times 10^{3}$ for kofta and $2.38 \times 10^{4} \pm$ $0.51 \times 10^{4}$ for sausage, respectively and according to Egyptian Orgnization for Standardization " EOS " ,the total Staphylococci count /g should be not more than $10^{2}(\mathrm{cfu} / \mathrm{g})$, therefore $64 \%, 88 \%$ and $44 \%$ of examined beef burger, kofta and sausage respectively, were unaccepted as recorded in table (2).

On the other hand, S.aureusdetected in $12(40 \%), 14(46.67 \%)$ and $19(63.33 \%)$ in examined samples of beef burger, koftaand sausage, respectively with mean value of $8.71 \times 10^{2} \pm 1.49 \times 10^{2}(\mathrm{cfu} / \mathrm{g})$ for beef burger, $3.10 \times 10^{3} \pm 0.74 \times 10^{3}(\mathrm{cfu} / \mathrm{g})$ for kofta and $5.96 \times 10^{3} \pm 0.88 \times 10^{3}(\mathrm{cfu} / \mathrm{g})$ for sausage, respectively as recorded in (table 3 ). 
Seriological examination declared that the incidence of Staphylococcus species from examined samples of locally manufactured meat products is $40 \%, 23.33 \%$ and $3.33 \%$ for S.aureus, S.epidermidis and S.intermedius, respectively could be isolated from beef burger, $46.67 \%, 26.67 \%$ and $6.67 \%$ for S.aureus, S.epidermidis and S.saprophyticus, respectively could be isolated from kofta and $63.33 \%, 36.67 \%, 10 \%, 13.33 \%$ and $6.67 \%$ for S.aureus, S.epidermidis, S.intermedius, S.saprophyticus and S.xylosus, respectively could be isolated from sausage samples as recorded in ( table 4) and the isolation percent was calculated according to the number of examined samples .

While, the incidence of S.aureus enterotoxins isolated from examined samples of locally manufactured meat products were enterotoxin B from beef burger with incidence of $3.33 \%$, enterotoxin A (one sample) and enterotoxin $\mathrm{C}$ (one sample) with incidence of $3.33 \%$ and $33.3 \%$, respectively from kofta samples, while enterotoxin $\mathrm{A}(3$ samples), $\mathrm{B}$ (one sample) and $\mathrm{D} \& \mathrm{C}$ (one sample) were isolated from sausage samples with incidence of $10 \%, 3.33 \%$ and $3.33 \%$ respectively as recorded in ( table 5).

Table (1): Incidence and Staphylococci count/g in the examined samples of locally manufactured meat products $(n=30)$.

\begin{tabular}{|c|c|c|c|c|c|}
\hline \multirow[b]{2}{*}{ Meat Products } & \multicolumn{2}{|c|}{ +ve samples } & \multirow[b]{2}{*}{ Min } & \multirow[b]{2}{*}{$\operatorname{Max}$} & \multirow[b]{2}{*}{ Mean \pm S.E } \\
\hline & No. & $\%$ & & & \\
\hline Beef burger & 30 & 100 & $1.0 \times 10^{2}$ & $8.6 \times 10^{3}$ & $4.07 \times 10^{3} \pm 0.69 \times 10^{3}$ \\
\hline Kofta & 30 & 100 & $2.0 \times 10^{2}$ & $1.9 \times 10^{4}$ & $9.52 \times 10^{3} \pm 2.14 \times 10^{3}$ \\
\hline Sausage & 30 & 100 & $5.0 \times 10^{2}$ & $7.2 \times 10^{4}$ & $2.38 \times 10^{4} \pm 0.51 \times 10^{4}$ \\
\hline
\end{tabular}

S.E ${ }^{*}=$ Standard error of mean 
Table (2): Acceptability of the examined samples of locally manufactured meat products based on their Staphylococci counts/g $(n=30)$.

\begin{tabular}{lllclc}
\hline \multirow{2}{*}{ Products } & $\begin{array}{l}\text { Staphylococci } \\
\text { count } / \mathrm{g}\end{array}$ & \multicolumn{2}{l}{ Accepted samples } & \multicolumn{2}{c}{ Unaccepted samples } \\
& $>10^{2}$ & 9 & $\%$ & No. & $\%$ \\
\hline Beef burger & $>10^{2}$ & 3 & 12 & 22 & 88 \\
Kofta & $>10^{2}$ & 14 & 56 & 11 & 44 \\
Sausage & & & & & 16 \\
\hline
\end{tabular}

Egyptian Organization for Standardization "EOS" (2005).

No 1688-2005 for beef burger

No 1973-2005 for kofta

No 1972-2005 for sausage

Table (3): Incidence of $S$. aureus count/g in the examined samples of locally manufactured meat products $(n=30)$.

\begin{tabular}{lcclll}
\hline \multirow{2}{*}{ Meat Products } & \multicolumn{2}{l}{ +ve samples } & & \\
& No. & $\%$ & Min & Max & Mean \pm S.E \\
& & & & & \\
\hline Beef burger & 12 & 40 & $1.0 \times 10^{2}$ & $2.1 \times 10^{3}$ & $8.71 \times 10^{2} \pm 1.49 \times 10^{2}$ \\
Kofta & 14 & 46.67 & $1.0 \times 10^{2}$ & $6.5 \times 10^{3}$ & $3.10 \times 10^{3} \pm 0.74 \times 10^{3}$ \\
Sausage & 19 & 63.33 & $1.0 \times 10^{2}$ & $1.3 \times 10^{4}$ & $5.96 \times 10^{3} \pm 0.88 \times 10^{3}$ \\
\hline S.E $^{*}=$ Standard error of mean & & & \\
\hline
\end{tabular}


Table (4): Incidence of Staphylococcus species isolated from the examined of samples locally manufactured meat products $(n=30)$.

\begin{tabular}{|c|c|c|c|c|c|c|c|c|}
\hline \multirow{2}{*}{$\begin{array}{l}\text { Meat } \\
\text { products } \\
\text { Staphylococcus } \\
\text { Species }\end{array}$} & \multicolumn{2}{|c|}{ Beef burger } & \multicolumn{2}{|c|}{ Kofta } & \multicolumn{2}{|c|}{ Sausage } & \multicolumn{2}{|c|}{$\begin{array}{l}\text { Total } \\
(n=90)\end{array}$} \\
\hline & No. & $\%$ & No. & $\%$ & No. & $\%$ & No. & $\%$ \\
\hline Staphylococcus aureus & 12 & 40 & 14 & 46.67 & 19 & 63.33 & 45 & 50 \\
\hline $\begin{array}{l}\text { Staphylococcus } \\
\text { epidermidis }\end{array}$ & 7 & 23.33 & 8 & 26.67 & 11 & 36.67 & 26 & $\begin{array}{l}28.8 \\
9\end{array}$ \\
\hline $\begin{array}{l}\text { Staphylococcus } \\
\text { intermedius }\end{array}$ & 1 & 3.33 & 0 & 0 & 3 & 10 & 2 & 6.67 \\
\hline $\begin{array}{l}\text { Staphylococcus } \\
\text { saprophyticus }\end{array}$ & 0 & 0 & 2 & 6.67 & 4 & 13.33 & 5 & $\begin{array}{l}16.6 \\
7\end{array}$ \\
\hline Staphylococcusxylosus & 0 & 0 & 0 & 0 & 2 & 6.67 & 1 & 3.33 \\
\hline
\end{tabular}

N.B.

The isolation $\%$ was calculated according to the number of examined samples

Table (5): Incidence of enterotoxins of $S$. aureus isolated from the examined samples of locally manufactured meat products.

\begin{tabular}{lllllllll}
\hline \multirow{2}{*}{ Enterotoxin } & $\begin{array}{l}\text { Beef } \\
(30)\end{array}$ & burger & $\begin{array}{l}\text { Kofta } \\
(30)\end{array}$ & & $\begin{array}{l}\text { Sausage } \\
(30)\end{array}$ & \multicolumn{3}{l}{$\begin{array}{l}\text { Total } \\
(90)\end{array}$} \\
\cline { 2 - 8 } & No. & $\%$ & No. & $\%$ & No. & $\%$ & No. & $\%$ \\
A & 0 & 0 & 1 & 3.33 & 3 & 10 & 4 & 4.44 \\
B & 1 & 3.33 & 0 & 0 & 1 & 3.33 & 2 & 2.22 \\
C & 0 & 0 & 1 & 3.33 & 0 & 0 & 1 & 1.11 \\
D \& C & 0 & 0 & 0 & 0 & 1 & 3.33 & 1 & 1.11 \\
Total & 1 & 3.33 & 2 & 6.67 & 5 & 16.67 & 8 & 8.89 \\
\hline
\end{tabular}




\section{DISCUSSION:}

Meat products are gaining popularity because they represent quick easily prepared meals of low price from one side and render the processors to convert the various types of meat into unified products. On the other side, meat products are liable to harbour different types of microorganisms a long the chain through handling, processing, distribution and storage as well as preparation (Hassanien, 2004). Further foods from animal origins are naturally susceptible to contamination by S.aureus which then multiply and produce enterotoxins (Moraes et al., 2009).

According to table (1), nearly similar results were reported by (Abd El-Hamid, 2010) with incidence of $2.2 \times 10^{3} \pm 4.54 \times$ $10^{2}$ and $2.17 \times 10^{3} \pm 4.31 \times 10^{2} \mathrm{cfu} / \mathrm{g}$, for sausage and beef burger, respectively and the higher results were reported by (Abou Hussein, 2004) $5.38 \times 10^{5} \pm 9.7 \times 10^{4}$ and $9.6 \times 10^{5} \pm 2.1 \times 10^{5}$ for sausage and beef burger, respectively, (Talaat, 2009 ) $1.04 \times$ $10^{7} \pm 4.3 \times 10^{6}(\mathrm{cfu} / \mathrm{g})$ and $1.46 \times 10^{6} \pm 5.33 \times$ $10^{5}$ (cfu/g) for sausage and beef burger, respectively and (Ibrahim, 2015) $1.97 \times 10^{5} \pm$ $6.49 \times 10^{4}$ and $2.08 \times 10^{5} \pm 5.56 \times 10^{4}(\mathrm{cfu} / \mathrm{g})$ for examined sausage and beef burger, respectively. While lower result recorded by (Abd El Satter, 2016) with incidence of 3.05 $\times 10^{3} \pm 0.97 \times 10^{3}(\mathrm{cfu} / \mathrm{g})$ for kofta samples .

Concerning the results of table (3)nearly similar results for beef burger samples were recorded by ( Ibrahim, 2016 ) $30 \%$ positive samples with incidence of 1.02 $\times 10^{4} \pm 2.53 \times 10^{3} \mathrm{cfu} / \mathrm{g},($ Hassanien, 2004) $36 \%$ positive samples with incidence of 6.34 $\times 10^{3} \pm 1.02 \times 10^{3} / \mathrm{g}$ (Radwan, 2009) $36 \%$ and (Ahmed, 2011) 36\%for the same examined product. While, lower results were recorded by (Ouf, 2001) 20\%, (Essa and Makar, 2003) 18\%, (El said, 2005) 4\%, (Salah and SalahEldeen, 2005) 10\%, (Shahrazet al., 2012) 25\%, (Eldalyet al., 2014)10\% and
(Atiah, 2017) 15\% and higher results were recorded by (Al-kour, 2001) $2.27 \times 10^{3} \pm 0.82$ $\times 10^{3} \mathrm{cfu} / \mathrm{g}$ and (Abd El-Hady, 2015) recorded $50 \%$ positive $S$. aureus samples in the same product.On the other hand, concerning to kofta samples lower results were recorded by (Hassanien, 2004) 24\% positive samples for the suspected S.aureus with mean value of $2.51 \times 10^{3} \pm 0.31 \times 10^{3}(\mathrm{cfu} / \mathrm{g})$ and $(\mathrm{Abd} \mathrm{El}$ Satter, 2016$)$ with mean value of $4.3 \times 10^{2} \pm$ $2.06 \times 10^{2}(\mathrm{cfu} / \mathrm{g})$. For the sausage samples : nearly similar results recorded by (Hassanien, 2004 ) $52 \%$ positive samples with mean value of $1.12 \times 10^{3} \pm 0.17 \times 10^{3}(\mathrm{cfu} / \mathrm{g})$ while, lower results recorded by (Ibrahim, 2016 ) (22\%) positive S.aureus samples with mean value of $3.03 \times 10^{3} \pm 6.33 \times 10^{2}$, ( Eldaly et al., 2014) $20 \%$ positive sausage samples with mean value of $2.1 \times 10^{4} \pm 0.5 \times 10^{4}$, (Ouf, 2001) $10 \%$, ( Farid, 2001) $20 \%$, (El said, 2005)10\%, (Salah and Salah Eldeen, 2005) 16.6\%, (Esteves et al.,2006) 40\%, (Mohamed, 2009) $31.43 \%$, (Seham et al., 2013) $20 \%$ and (Armany, 2016) 24\% and higher result recoded by (Abou Hussien, 2004) 72\% positive Saureus in examined sausage samples.

Furthermore, S.aureus was isolated previously by (Ibrahim, 2016); (Armany, 2016) and (Abou Hussien, 2004) from sausage samples, (Abd El Satter, 2016 ) and (Hassanien, 2004) from beef burger and kofta samples, while S.epidermidis, S.intermedius, S.saprophyticus were isolated from beef burger and kofta samples by (Abd El Satter, 2016 )with incidence rate of $42 \%, 16 \%$ and $26 \%$ in beef burger \& $22 \%, 34 \%$ and $12 \%$ in kofta samples, respectively.

Staph. aureus may produce numerous numbers of enterotoxins (A, B, C, D, E, G, H, I, J, K, L, M, N, O, P, Q, R and U), but $95 \%$ of poisoning outbreaks are caused by classical enterotoxins: A, B, C, D and E (Letertre et al., 2003) and considered as a leading cause of food poisoning resulting from the 
consumption of contaminated food with staphylococcal enterotoxins. Different foods can act as a good medium for S.aureus such meat products (Guven et al., 2010). )and the symptoms of staphylococcal food poisoning are abdominal cramps, nausea, vomiting, sometimes followed by diarrhea (never diarrhea alone). The onset of symptoms remission is observed after $24 \mathrm{~h}$ (Le Loir, 2003).

Presence of S.aureusin meat products may be attributed to direct contact with workers with hand or arm lesions caused by S.aureus, or by coughing and sneezing which is common during respiratory infections. Food handlers are frequently the source of food contamination in staphylococcal outbreaks (Jennifer Hait, 2012)so, microorganisms control in meat products is the major concern in the preparation of high quality foods especially during slaughtering process as the meat is exposed to many sources of contamination such as hands of workers, water, air and equipments (Jo et al.,2004) and sanitation programs address issues such as personal hygiene, hygienic work practices, employee education and proper cleaning and sanitization protocols. Knives, gloves and aprons are among a number of pieces identified as potential reservoirs of bacteria if not cleaned or sanitized properly (Dean, 2007).

\section{CONCLUSION}

This study concluded that the examined meat products of (beef burger, kofta and sausage) from local commercial retail shops in Menofia government harbor a high microbial loads of S.aureus and this is due to contamination during different processing stages or due to using of contaminated materials as spices or contamination during handling and from surrounding and poor sanitary conditions which lead to inferior quality product and become unfit for consumption. Also S. aureus enterotoxins which were detected in the examined samples have public health hazard.

$S$. aureus currently attracted increasing attention due to its capability of producing a range of enterotoxins and tissue degrading enzymes and become a leading cause of food poisoning resulting from the consumption of contaminated food with staphylococcal enterotoxins, therefore, microorganisms control in meat products is the major concern in the preparation of high quality foods.

\section{REFERENCES}

Abd El Satter - Alaa M. (2016): Incidence and importance of some pathogenic microorganisms contaminating meat product. M. V. Sc. Thesis (Meat Hygiene), Fac of Vet. Med. BenhaUniv, Egypt.

Abd El Hady, A. M. (2015): Bacteriological and molecular characterization of Staph.aureus from beef meat products in El Gharbia Province. M.V.SC. Thesis, Fac. Vet. Med.Cairo Univ, Egypt.

Abd El-Hamid, M. A. (2010): Detection of some food poisoning microorganism in some meat products.M.V.Sc. Thesis, Fac. Vet. Med. Alex. Univ. Egypt.

AbouHussien - Reham A. (2004): Microbial evaluation of some meat products. M. V. Sc. Thesis (Meat hygiene), Fac. Vet. Med. Moshtohor, Zagazig Univ, (Benha branch). Egypt.

Ahmed, S. M. E. (2011): Occurence of Staphylococci and E. coli in ground beef and some processed meat. M. V. Sc. Thesis, Meat Hygiene ‘Fac. Vet. Med. Alex. Univ. Egypt.

Al-Kour, M. S. (2001): Microbiological status of meat and some meat products in northern Jordan.M. V. Sc. Thesis, Meat Hygiene, Fac. Vet. Med., 
Jordan Univ. Science and Technology..

Armany. G. A. (2016): Detection of foodborne medicated pathogens in some meat products by using Multiplex PCR Technique. M. V. Sc. Thesis ( Meat Hygiene), Fac of Vet. Med. Benha Univ. Egypt.

Atiah - Aboubakr (2017): E.coli and S.aureus in some meat and poultry products. Ph.D, Thesis ( Meat Hygiene), Fac of Vet. Med. Benha Univ,Egypt.

CDC (Centers for disease control and prevention) (2006): Staphylococcal Food Poisoning. Available on http://www.cdc.gov/dbmd/diseaseinfo Istaphylococcusfoodg.htm.

Dean, O. C. (2007) :Microbialdecontamination, Food Safety, and Antimicrobial interventions .

Eldaly, E.A.; Nermeen, F. El Shopary and Rasha, M. El Bayomi (2014): Detection of enterotoxigenic S.aureusgenes prevalentin some meat products using Multiplex PCR. The $1^{\text {st }}$ Int. Conf. On The Impact of Environmental Hazards On Food Safety, ZagazigUniv J. August $20^{\text {th }}$ 2014. p 162-168. Egypt.

El-Said, SH. A. A. (2005): Psychrophilic microorganisms in frozen meat products. M. V. Sc. Thesis (Meat Hygiene), Fac of Vet. Med. Zagazig Univ. Egypt.

Essa, H. H. and Makar, N. H. (2003):Bacteriological quality of beef burgers in Assuit City, Assuit. Vet. Medical Journal, 49(9) : 81-88. Egypt.

Farid, H. M. H. (2001):Study on gram positive bacteria in meat products, Ph.D. V. Sc. Fac. Vet. Med.Beni-Suef Univ. Egypt.
Feldman, D.; Ganon, J.; Haffman, R. and Simpson, J. (2003): The solution for data analysis and presentation graphics. $2^{\text {nd }}$ Ed., Abacus Lancripts, Inc., Berkeley, USA.

Food and Drug Administration "FDA" (2001): S.aureus. Bacteriological analytical manual $\quad .8^{\text {th }} \quad$ Ed. Chapter12.Academic Press, Gaithersburg, UK.

Food Safety and Inspection Service. (FSIS)(2003): Meat preparation : Beef from farm to table. United States Department of Agriculture. Washington. DC. 20250-3700.

Gibbons, I.; Adesiyun, A.; Nadira, S.; Rahaman, S. (2006): investigation for possible sources of contamination of ready-to-eat meat products with Listeria species and other pathogens in a meat processing plant in Trinidad. Food Microbiol., 23(4): 395-366.

Guven, K. ;Mutlu, M. B. ; Gulbandilar, A. and Cakir, P. (2010) : Occurrence and characterization of $S$. aureus isolated from meat and dairy products consumed in Turkey. J. Food Safety 30(1): 196-212.

Hassanien - Fatin S. (2004): Bacterial hazards associated with consumption of some meat products. Benha Vet. Med. J., 15(2): 41-54. Egypt.

Hiip;//wwwcdfa.ca.gov/ahfss/Animal_Health/ PHR250/2007/25007Antimic.Pdf.

Ibrahim - Shimaa M. A. (2016):Detection of $S$. aureus classic enterotoxin genes in some meat products using multiplex PCR. M. V. Sc. Thesis ( Meat Hygiene), Fac of Vet. Med. Benha Univ. Egypt.

International commission of Microbiological Specification for Foods "ICMSF" (1996):Microorganisms in Food. ITheir Significance and methods of 
enumeration. $3^{\text {rd }}$ Ed. Univ. of Toronto, Canada.

Jennifer Hait, B. S. (2012): Handbook of Foodborne Pathogenic Microorganisms and Natural Toxins. S. aureus. In Bad Bug Book, (ed.2).

Jo, C.; Lee, N.Y.; Kang, H.J.; Shin D.H. and Byun, M.W. (2004): Inactivation of food borne pathogens in marinated beef rib by ionizing radiation. J. Food Microbiol. 21: 543-548.

Le Loir, Y.; Baron, F. and Gautier, M. (2003): $S$. aureus and food poisoning. Genet.Mol. Res., 2(1): 63-76.

Letertre, C.; Perelle, S.; Dilasser, F. and Fach, P. (2003): Identification of a new putative enterotoxin SEU encoded by the egc cluster of S. aureus. J. Appl. Microbiol., 95(1): 38-43.

Mohamed, I. A. I. (2009):Bacteriological quality and shelf life of some meat products. M.V.Sc., Meat Hygiene, Fac. Vet. Med. Alex. Univ.Egypt

Moraes, P. M.; Viçosa, G. N.; Yamazi, A. K.; Ortolani, M. B. T. andNero, L. A. (2009): Foodborne pathogens and microbiological characteristics of raw milk soft cheese produced and on retail sale in Brazil. Foodborne Pathogens and Disease, 6:245-249.

Nestle, M. (1999): “Animal v. plant foods in human diets and health: Is the historical record unequivocal?" Proceedings of the Nutrition Society, 58(2): 211-218.

Oda, T.; Ohkubo, T.; Nagai, M.; Nishimoto, Y. and Ohmoruk, K. (1979): Detection of Staphylococcal enterotoxins in foods by RPLA test. Ann. Rep. Funkauka City, Japan.Hyg. Lab.4: 33-37.

Ouf - Jehan M., (2001) : Microorganisms of sanitary importance in some meat products and their additives.
Ph.D.Thesis, Meat Hygiene. Fac. Vet. Med., Cairo Univ.Egypt.

Radwan, S. A. S. (2009): Shelf life assessment of some ready to eat meat products at refrigeration temperatures through their microbial and chemical contents. M.V.Sc.,meat hygiene, Fac. Vet. Med. Alex. Univ.Egypt.

Salah, M. A. and Salah El-Din, W. M. (2005): Microbiological studies on some meat products at Sharkia governorate markets Zag. Vet. J. (ISSN. 11101458) 33: 141-151.Egypt.

Sandel, M.K. and Mckillip, J.L. (2004): Virulence and recovery of S.aureus relevant to the food industry using improvements on traditional approaches. J. Food Control. 15:5-10.

Seham, A. Ismail; Amal, A. Shehata and Eldiasty, E.M. (2013): Microbiological quality of some meat products in local markets with special reference to mycotoxins. Global Veterinaria, 10 (5): 577-584.

Shahraz, F. ; Dadkhah, H. ; Khaksar, R. ; Mahmoudzadeh, M. ,Hosseini, H. ; Kamran, M. and Bourke, P. (2012) :Analysis of antibiotic resistance patterns and detection of mecA gene in Staph. aureus isolated from hamburger. Meat sci, 90:759-763.

Shingaki, M.; Igarashi, H.; Fujikawa, H.; Ushioda, H.; Terayrna, T. and Sakai, S. (1981): Study on Reversed Passive Latex Agglutination for detection of staphylococcal enterotoxins A, B, and C. Annu.; Rep. Tokyo, metro p. Res.Lab.Public Health; 32(1): 128131.

Stevenson, K.F. and Bernard, D.T. (1995): Establishing hazard analysis in critical control point programs. A workshop Manual, 2nd.Ed. 4th, Food Processors Institute, Washington, D.C.

Talaat- Nagwa W. (2009): Bacteriological and histological evaluation of some meat products. M. V. Sc. (Meat hygiene), Fac. Vet. Med. Kafrelsheikh Univ.Egypt. 